\title{
Analysis of Soil Erodibility Factor for Hydrologic Processes in Kereke Watershed, North Central Nigeria
}

\author{
1*SONGU, GA; ${ }^{1} \mathrm{ABU}, \mathrm{RD} ;{ }^{1}$ TEMWA, NM; ${ }^{2}$ YIYE, ST; ${ }^{1}$ WAHAB, S; ${ }^{1}$ MOHAMMED, \\ BG
}

\author{
${ }^{*}$ Department of Geography, Federal University of Kashere, Gombe State, Nigeria. \\ ${ }^{2}$ Department of Geography, Benue State University, Makurdi, Nigeria \\ *Corresponding Author Email: godwinsongu22@gmail.com; Tel: +234 7031028175
}

\begin{abstract}
Soil erodibility factor plays essential role in determining how susceptible soil is to hydrological processes such as detachment and removal by rainfall and runoff that could influence soil erosion and sediment entrainment by flooding in an area. This paper therefore determined the erodibility k-value of soil in the Kereke watershed with the purpose of assessing its susceptibility to hydrological processes. Data was collected on some soil properties such as soil texture, soil structure, soil organic matter content, soil carbon content, soil porosity, soil bulk density, soil moisture content and soil erodibility k-value. The systematic sampling procedure was used to select thirty-two settlements which served as catchment areas for data collection; from which thirty-two soil samples were collected for analysis. Tables and graph were used to present the data, and percentages were used to depict variations in the data set. Results of the study shows that the soil samples have high percent sand particles (71.6\%), moderate amount of clay particles (15.7\%), silt $(12.7 \%)$, organic carbon $(0.6 \%)$, organic matter $(1.1 \%)$, bulk density $\left(1.4 \mathrm{gcm}^{-3}\right)$, porosity $(45.2 \%)$, moisture content $(14.0 \%)$ and low soil erodibility k-value of 0.018 . The soil erodibility k-value in the study area was considered to be low, and therefore the soils are moderately erodible. This probably accounts for the moderate intensity of soil erosion channels and entrained sediments by flooding observed in the study area. It is therefore recommended that soil management practices should be encouraged by farmers especially planting of cover crops, shifting cultivation and fallowing system. This will allow nutrients gain and improved bulk density to limit soil erodibility capacity and good soil management in the area.
\end{abstract}

\section{DOI: https://dx.doi.org/10.4314/jasem.v25i3.18}

Copyright: Copyright (C) 2021 Songu et al. This is an open access article distributed under the Creative Commons Attribution License (CCL), which permits unrestricted use, distribution, and reproduction in any medium, provided the original work is properly cited.

Dates: Received: 12 December 2020; Revised: 26 January 2021; Accepted: 12 February 2021

Key words: Soil erodibility factor, hydrological processes, Kereke watershed, North Central Nigeria

Soil erodibility factor ( $\mathrm{k}$ - factor) influence hydrologic processes such as runoff, soil erosion and flooding in a watershed; by determining the infiltration rates and amount of sediment that can be eroded from the top soil. Soil erodibility is conceptualized as the intrinsic susceptibility or inherent yielding of a soil particles to detachment and transportation by raindrop impact and runoff. The soil erodibility factor was devised by the Natural Resources Conservation Service (NRCS) for use in estimating soil losses with the Universal Soil Loss Equation (USLE) (Ostovari, 2019). A high erodability implies that the same amount of work exerted by the erosion processes leads to a larger removal of earth materials in a watershed. Udosen (2013) noted that soil erodibility is dependent on environmental variables such as vegetation cover, slope inclination, root content, depth of litter cover, soil porosity, silt/clay ratio, soil texture and organic matter content. Most importantly, these parameters determine the volume of runoff on slopes; in turn influences the rate of soil that can be removed in a watershed at any given time. Okorafor et al., (2017)) reported that soils with a large amount of silt-sized particles are most susceptible to erosion from both wind and water; while soils with clay or sand-sized particles are less prone to soil erosion. This is because silt particles have less organic matter and therefore more loose than clay particles which are rich in organic matter content. The organic matter content present in clay soils bind the particles together and thereby reducing its susceptibility to detachment and entrainment. Also, organic matter protects the soil by shielding it from the impact of falling rain and soaking up rainfall that would otherwise become runoff (Shahrivar \& Christopher, 2012). While, soil structure defines the degree to which soil particles are clumped together, forming larger clumps and pore spaces; it influences both the ability of the soil to absorb water and its physical resistance to erosion and flooding (Okorafor et'al, 2017). Shahrivar and Christopher (2012) in their study on susceptibility of the soils to gully erosion in Kohgiloyeh and Boyer Ahmad 
Province, Iran observed that soil texture groups showed that the gully length and volume were increased from loam to clay loam. The gullies' frequency also showed that gullies with silt loam and silt clay loam texture in their surface and deeper layer respectively had the most frequency. While, the gullies with silt loam in their surface layer and loam in deeper layer had the least number of gullies. The longer lengths of gullies observed in areas with loamy soils compared to areas with clay loam, was attributed to the higher organic matter content present in the clay loam soils, which seemed to be more resistant to been eroded. Moreover, comparison of the gully and control indicated that there is a significant difference between the two areas in terms of sand and silt. The amount of sand and silt in the gully control areas were higher than the gully erosion areas.

In the Kereke watershed, gullies of different sizes and flash floods have been observed and reported by different scholars. For instance Iorkua (1999) reported a sizeable gully of about $330 \mathrm{~m}$ long which was incised in the area. Songu et'al (2015) reported that about $12,575.28$ tonnes of sediments were removed from a third order gully catchment in the watershed due to runoff. Moreover, Songu (2019) reported gullies of different sizes ranging from $110 \mathrm{~m}$ to $300 \mathrm{~m}$ long which were incised in the Kereke watershed as a result of raindrop impact and runoff in combination with other environmental variables. Also, Iorkua et'al (2018) reported the deposition of alluvium on the flood plains of River Benue, and nearby settlements due to flooding in the watershed with socio-economic consequences on the people.

The occurrence of these hydrological processes in the humid tropical environment of the Kereke watershed implies that the soil particles in the watershed are susceptible to erosion by water and flooding. However, quantification of the soil erodibility factor ( $\mathrm{k}$ - factor) in the watershed, which ought to be useful for soil management, gully erosion and flood control is deficient in literature. It is against this backdrop that this paper determined the soil erodibilty $\mathrm{k}$-value in Kereke watershed, to enhance the control of hydrological processes such as soil erosion and flooding for environmental sustainability; as well as bridge literature gaps. Hence, the objective of this paper is to analyse soil erodibility factor for hydrologic processes in Kereke Watershed, North Central Nigeria.

\section{MATERIALS AND METHODS}

The study was conducted in the Kereke watershed of the lower Benue Trough. The study area lies between latitude $7^{0} 36^{\mathrm{I}} \mathrm{N}$ and $8^{0} 20^{\mathrm{I}} \mathrm{N}$ and between longitude $8^{0} 28^{\mathrm{I}} \mathrm{E}$ and $8^{0} 50^{\mathrm{I}} \mathrm{E}$ (Ministry of Lands and Survey Makurdi, 2016). The Kereke watershed like other parts of the Benue Trough experiences wet and dry climate known as "Aw" by Koppen's climatic classification scheme. This type of climate is also called the tropical humid savanna climate (Tyubee, 2005). The wet season which last for seven months starts from April and ends in October. Conversely, the dry season starts from November and ends in March. The climate is usually associated with torrential rainfall and high temperatures. The annual total rainfall ranges from $1000 \mathrm{~mm}$ to $2000 \mathrm{~mm}$, with an average annual intensity of $44.85 \mathrm{~mm} / \mathrm{hr}$ (NIMET, 2015). Temperatures are high throughout the year, averaging $27^{\circ} \mathrm{c}$ to $31^{\circ} \mathrm{c}$. Though, it may occasionally rise to $37^{\circ} \mathrm{c}$ in some days in March and April. The study area is confined in the Guinea Savanna region of the Benue valley. It is therefore characterised with shrubs, grasses and trees. Some of tree species in the study area include: Raphia palm (Raphiasudanica), sheabutter trees (Butrospernum paradoxum), Malina (Gmelinaarborea), Obeche (Afzetia Africana), locust bean trees, Mahogany, Iroko trees. Other economic trees found in the study area are Mango (mangiferaindica), Cashew tree (Anacardiunaccidentale), Guava (Psidiumguajava), Pawpaw (Caricapapaya), Palm tree (Elaeisguinniensis), Banana (Musaspp) and Sweet orange (citrussinensis).

The geology is predominantly sandstone. The sedimentary basins found within the Benue trough aulocogen comprises of older and younger sedimentary rocks formed between Paleozoic and Cenozoic era of geologic time scale (Benkhelil, 1989). The superficial geology of the Benue trough is largely meta-sediments, predominantly comprised of alluvial deposits made up of sand, clay, silt, gravel and pebbles and forms the dominant surface geology of the study area (Benkhelil, 1989). The study area is endowed with erodible soils, which are predominantly deep, sandy and are derived from alluvial deposits. The soil is well drained and so the water holding capacity is limited; and more so, because the soil has moderate organic matter content which enhances permeability (Aneke, 1991). The Kereke watershed has an undulating terrain with slope angle exceeding $10^{\circ}$ in some steep areas. Its general topography varies between $69 \mathrm{~m}-255 \mathrm{~m}$ as analysed from Satellite Imagery (SRTM) of the study area. The Kereke watershed is a $4^{\text {th }}$ order drainage basin, with a total of fifty-nine $1^{\text {st }}$ order streams, twenty-seven $2^{\text {nd }}$ order streams, twelve $3^{\text {rd }}$ order streams and one $4^{\text {th }}$ order stream. The Kereke watershed has an average bifurcation ratio of 5.48. The moderate bifurcation ratio could be attributed to the sedimentary rocks which underlain the basin and moderate rainfall intensities. The mean bifurcation ratio of 5.48 implied 
that the dissection of the Kereke drainage basin is coarse and this could influence channelised flow especially at the lower segment of the basin and thereby influencing gully initiation and flooding in some parts of the basin. Figures 1 and 2 are location and relief maps of the study area.

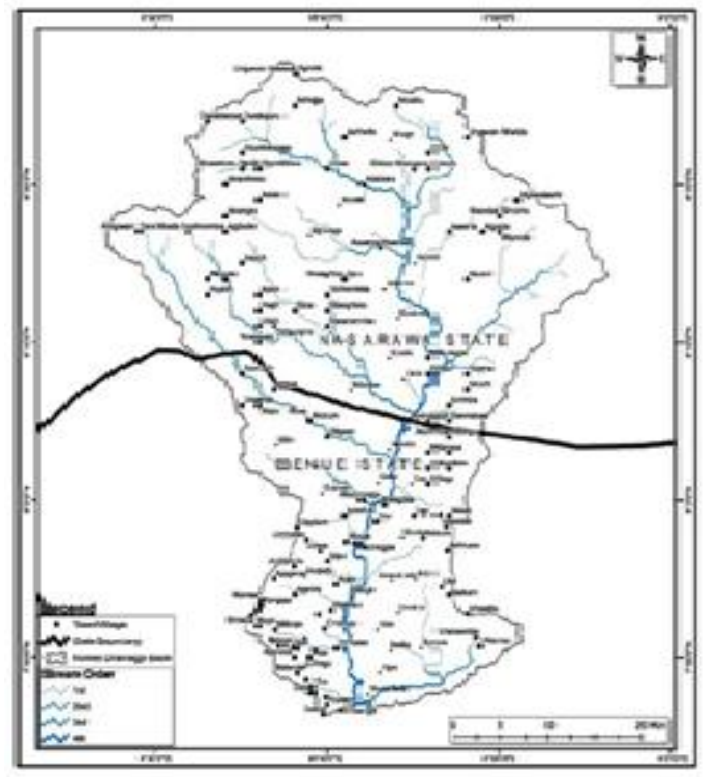

Fig 1: Location of Kereke watershed

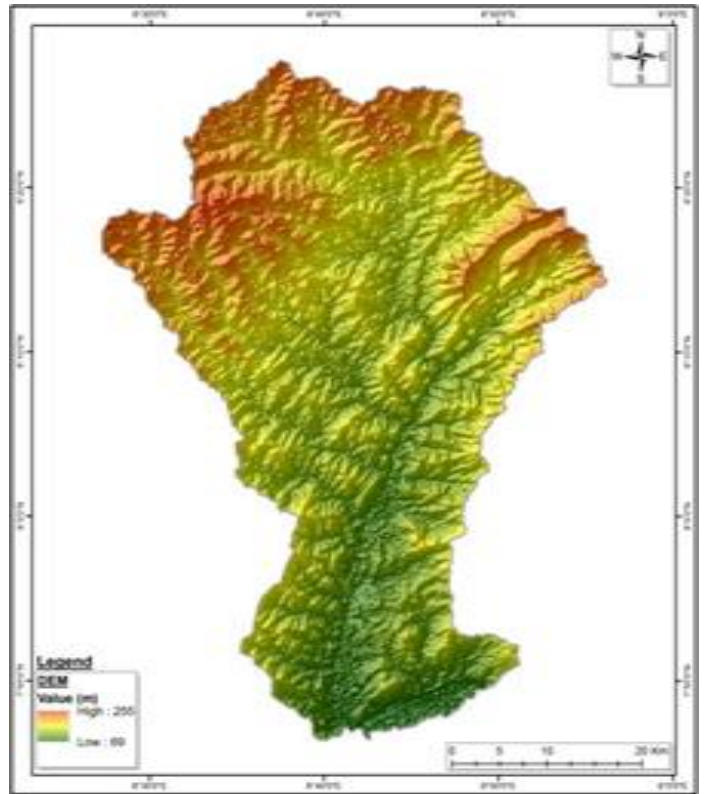

Fig.2: DEM of Kereke watershed showing variation in relief Source: Authors' GIS Analysis from SRTM, 2019

The field observation design with emphasis on direct field measurements was adopted in this study. Sample size for the study was determined by using topographic map sheets Makurdi $251 \mathrm{NW}$, Makurdi $251 \mathrm{NE}$, Makurdi $251 \mathrm{SW}$ and Makurdi 251SE at the scale of 1:50,000; published by the Federal survey of
Nigeria in 1970 (Office of the Surveyor General of Nigeria, 2016). The entire Kereke watershed which is $372.41 \mathrm{~km}^{2}$ identified on the map, was covered with network of grid lines at interval of $1 \mathrm{~cm}$; which represented $500 \mathrm{~m}$ on the ground. All the grids were then numbered; and the total number of grid cells covering the drainage basin were 62 ; representing the sample frame. The systematic sampling procedure was then used to select 32 grid cells at every second grid cell, which represented interval of $1 \mathrm{~km}^{2}$ for data collection. The systematic sampling procedure was achieved by selecting the grids with even numbers, and with a starting point of 0 . Location of the sampled grids is shown in Table 1.

\begin{tabular}{|c|c|c|}
\hline $\mathbf{S} / \mathbf{N}$ & $\begin{array}{l}\text { Selected Grid } \\
\text { Number }\end{array}$ & $\begin{array}{l}\text { Settlement } \\
\text { (catchment area) }\end{array}$ \\
\hline 1 & 0 & $\begin{array}{l}\text { Low cost housing, } \\
\text { North Bank }\end{array}$ \\
\hline 2 & 2 & Agan \\
\hline 3 & 4 & Daudu \\
\hline 4 & 6 & Ikpam \\
\hline 5 & 8 & Gide \\
\hline 6 & 10 & Iyorkyaa \\
\hline 7 & 12 & Akiki \\
\hline 8 & 14 & Kwabo \\
\hline 9 & 16 & Gever \\
\hline 10 & 18 & Asamakaha \\
\hline 11 & 20 & Ukpiam \\
\hline 12 & 22 & Ajo \\
\hline 13 & 24 & Kyaan \\
\hline 14 & 26 & Usan \\
\hline 15 & 28 & Amala \\
\hline 16 & 30 & Agena \\
\hline 17 & 32 & Hinyam \\
\hline 18 & 34 & Yerewata \\
\hline 19 & 36 & Ande \\
\hline 20 & 38 & Kyado \\
\hline 21 & 40 & Kadarko \\
\hline 22 & 42 & Akumba \\
\hline 23 & 44 & Gogo \\
\hline 24 & 46 & Achuwa \\
\hline 25 & 48 & Gaval \\
\hline 26 & 50 & Giza \\
\hline 27 & 52 & Ume \\
\hline 28 & 54 & Adobi \\
\hline 29 & 56 & Aloshi \\
\hline 30 & 58 & Agyaragu \\
\hline 31 & 60 & Adugu \\
\hline 32 & 62 & Agaza \\
\hline
\end{tabular}

Data on soil properties such as soil texture, soil structure, soil organic matter and carbon content, soil porosity, soil bulk density, soil moisture content and soil erodibility k-value were determined from the field and laboratory as shown below:

(i) Soil texture: It refers to the proportion of sand, silt and clay sized particles that make up the mineral fraction of the soil (Nyle \& Brady, 2000). Since the focus of this study was on soil erodibility, soil samples were taken from the top soil at the depth of $10 \mathrm{~cm}$ using 
a soil core sampler measuring $5.5 \mathrm{~cm}$ in height and $4 \mathrm{~cm}$ in width. Due to the varying nature of soils, five soil samples from different locations within a sampled settlement were aggregated into one soil sample to determine average soil characteristics in each sampled area. This is because soil characteristics differ within a small area, it therefore became necessary to collect soil samples from different points within a sampled grid for soil analysis to determine the average soil characteristics. The soil samples from the sampled grids were then taken to the soil science laboratory at University of Agriculture, Makurdi in labeled polythene bags for determination of particle size distribution and other soil characteristics. The samples were air dried and passed through $2 \mathrm{~mm}$ mesh or sieve and the hydrometer method was used for determination of particle size distribution in soil samples as described by Nyle and Brady (2000).

(ii) Soil structure: Soil structure describes the arrangement of the solid parts of the soil and of the pore space located between them. It is determined by how individual soil granules clump, bind together and aggregate, resulting in the arrangement of soil pores between them (Nyle \& Brady, 2000). The arrangement of soil aggregates were observed on the field with the aid of a hand held lens. The arrangement of soil aggregates were examined and described either as fine granular, coarse granular, crumb, blocky or platy following Ahn (1971) specifications. Also, the identified soil structures were coded as (1), (2), (3) and (4) respectively and used in determining soil erodibility $\mathrm{K}$-factor by assigning absolute values in that order viz. 1, 2, 3 and 4 as described by Wischmeier and Smith (1978).

(iii) Soil organic matter and carbon content: Soil organic matter is the organic matter component of soil, consisting of plant and animal residues at various stages of decomposition, cells and tissues of soil organisms, and substances synthesised by soil organisms (Brady \& Weil, 1999). Soil organic matter content exerts numerous positive effects on soil physical and chemical properties, as well as the soil's capacity to resist soil erosion. The soil organic matter and organic carbon contents were determined in the laboratory by using the wet oxidation method as described by Brady and Weil (1999). The organic matter content was expressed as percentage of organic matter per giving wet of soil sample.

(iv) Soil porosity: Soil porosity is a measure of the void spaces in soil, and is a fraction of the volume of voids over the total volume of soil measured as a percentage between $0 \%$ and $100 \%$. Soil porosity is affected by soil particle texture, soil structure, soil compaction and quantity of organic material. Soil with fine texture is able to hold more water than soil with coarse texture (Brady \& Weil, 2000). The result was expressed in percentage.

(v) Soil bulk density: Soil bulk density is an indicator of soil compaction or the weight of soil in a given volume. It is calculated as the dry weight of soil divided by its volume. This volume includes the volume of soil particles and the volume of pores among soil particles. Bulk density is typically expressed in $\mathrm{g} / \mathrm{cm}^{3}$ (Brady \& Weil, 2000; Houston et'al, 2013). The soil bulk density was determined by using a McCauley corer of approximately $4 \mathrm{~cm}$ in diameter and $5.5 \mathrm{~cm}$ in height to collect samples of soil from the sampled areas and carefully labeled on the field. The soil samples were then taken to soil science laboratory at University of Agriculture Makurdi, where they were oven dried and weighed.

(vi) Soil moisture content: This is the amount of water contained in the pore spaces of soil in a given soil sample. The soil moisture content was determined by using a McCauley corer of approximately $4 \mathrm{~cm}$ in diameter and $5.5 \mathrm{~cm}$ in height to collect samples of soil from the sampled areas and carefully labeled on the field. The soil samples were then taken to soil science laboratory at University of Agriculture Makurdi, where they were weighed before and after oven dried to determine the moisture content of the soil in natural state.

(vii) Soil erodibility $k$-value: The soil erodibility factor (K-factor) is a quantitative description of the inherent erodibility of a particular soil; it is a measure of the susceptibility of soil particles to detachment and transport by rainfall and runoff (Charlton, 2008). The soil erodibility $\mathrm{k}$-value was determined using the Revised Universal Soil Loss equation (RUSLE) as elaborated by Wischmeier, Johnson and Cross (1971). The equation is giving as:

$$
\begin{aligned}
& K=2.8 \times 10-7 \times M 1.4[12-a]+ \\
& 4.3 \times 10-3[b-2]+3.3 \times 10-3[c-3]
\end{aligned}
$$

Where $a=$ is the percent organic matter; $b=$ is the soil structure code (i.e. fine granular, 1; coarse granular, 2; crumb, 3 and blocky or platy, 4$) . \mathrm{C}=$ the profile permeability class (i.e. rapid, 1; moderate, 2; slow, 3 and very slow, 4)

\section{RESULTS AND DISCUSSION}

Soil Properties in the Kereke Watershed: Soil properties such as soil texture, soil structure, organic matter content, bulk density, porosity and soil moisture content were determined in the study. Results of the soil analysis are contained in Table 2. 


\begin{tabular}{|c|c|c|c|c|c|c|c|c|}
\hline $\mathbf{S} / \mathbf{N}$ & $\begin{array}{l}\text { Sand } \\
(\%)\end{array}$ & $\begin{array}{l}\text { Clay } \\
(\%)\end{array}$ & $\begin{array}{c}\text { Silt } \\
(\%)\end{array}$ & $\begin{array}{l}\text { Organic } \\
\text { Carbon } \\
(\%)\end{array}$ & $\begin{array}{l}\text { Organic } \\
\text { Matter } \\
(\%)\end{array}$ & $\begin{array}{l}\text { Buck } \\
\text { Density } \\
\mathrm{gcm}^{-3}\end{array}$ & $\begin{array}{l}\text { Porosity } \\
(\%)\end{array}$ & $\begin{array}{l}\text { Moisture } \\
(\%)\end{array}$ \\
\hline 1. & 68.24 & 18.48 & 13.28 & 0.6 & 1.03 & 1.42 & 37.73 & 13.49 \\
\hline 2. & 70.24 & 17.76 & 12.00 & 1.02 & 1.76 & 1.34 & 46.79 & 8.03 \\
\hline 3. & 80.24 & 10.48 & 9.28 & 0.22 & 0.38 & 1.46 & 47.55 & 17.41 \\
\hline 4. & 78.24 & 12.48 & 9.28 & 0.12 & 0.21 & 1.48 & 44.15 & 16.71 \\
\hline 5. & 72.24 & 16.48 & 11.28 & 0.92 & 1.59 & 1.45 & 45.28 & 18.74 \\
\hline 6. & 72.24 & 14.48 & 13.28 & 0.92 & 1.59 & 1.44 & 45.66 & 19.66 \\
\hline 7. & 70.24 & 16.48 & 13.28 & 0.20 & 0.34 & 1.30 & 44.91 & 10.31 \\
\hline 8. & 72.24 & 14.48 & 13.28 & 0.48 & 0.83 & 1.51 & 43.02 & 18.85 \\
\hline 9. & 68.24 & 16.48 & 15.28 & 0.56 & 0.97 & 1.30 & 44.91 & 15.74 \\
\hline 10. & 68.24 & 18.48 & 13.28 & 1.16 & 2.00 & 1.46 & 44.91 & 8.46 \\
\hline 11. & 74.24 & 14.48 & 11.28 & 0.60 & 1.03 & 1.49 & 43.77 & 12.11 \\
\hline 12. & 66.24 & 20.48 & 13.28 & 0.50 & 0.86 & 1.46 & 44.91 & 13.37 \\
\hline 13. & 70.24 & 16.48 & 13.28 & 0.52 & 0.90 & 1.13 & 46.04 & 8.54 \\
\hline 14. & 76.24 & 12.48 & 11.28 & 0.56 & 0.97 & 1.41 & 46.79 & 11.04 \\
\hline 15. & 76.24 & 11.48 & 12.28 & 0.44 & 0.76 & 1.41 & 46.79 & 8.72 \\
\hline 16. & 74.24 & 14.48 & 11.28 & 0.52 & 0.90 & 1.03 & 45.28 & 13.85 \\
\hline 17. & 70.24 & 14.48 & 15.28 & 0.52 & 0.91 & 1.23 & 46.04 & 12.91 \\
\hline 18. & 68.24 & 16.48 & 13.28 & 0.40 & 0.69 & 1.42 & 46.42 & 13.07 \\
\hline 19. & 76.24 & 12.48 & 11.28 & 0.46 & 0.79 & 1.43 & 46.04 & 12.75 \\
\hline 20. & 70.24 & 16.48 & 13.28 & 0.54 & 0.93 & 1.45 & 45.28 & 12.59 \\
\hline 21. & 68.24 & 18.48 & 13.28 & 0.58 & 1.00 & 1.44 & 45.66 & 19.87 \\
\hline 22. & 70.24 & 14.48 & 11.28 & 0.50 & 0.86 & 1.03 & 45.28 & 10.33 \\
\hline 23. & 66.24 & 18.48 & 15.28 & 0.62 & 1.07 & 1.32 & 44.53 & 17.65 \\
\hline 24. & 68.24 & 16.48 & 15.28 & 0.70 & 1.21 & 1.05 & 43.77 & 17.29 \\
\hline 25. & 74.24 & 14.48 & 11.28 & 0.56 & 0.97 & 1.50 & 43.40 & 12.13 \\
\hline 26. & 72.24 & 14.48 & 13.28 & 0.52 & 0.90 & 1.22 & 45.28 & 9.10 \\
\hline 27. & 72.24 & 16.48 & 11.28 & 0.64 & 1.10 & 1.23 & 44.15 & 23.36 \\
\hline 28. & 70.24 & 16.48 & 13.28 & 0.46 & 0.79 & 1.19 & 45.28 & 14.95 \\
\hline 29. & 74.24 & 14.48 & 15.28 & 0.40 & 0.69 & 1.45 & 43.02 & 19.33 \\
\hline 30. & 70.24 & 17.76 & 12.00 & 0.54 & 0.93 & 1.52 & 42.64 & 12.96 \\
\hline 31. & 72.24 & 16.48 & 11.28 & 0.34 & 0.59 & 1.45 & 45.28 & 10.25 \\
\hline 32. & 70.24 & 16.48 & 13.28 & 1.90 & 3.28 & 1.46 & 44.91 & 15.18 \\
\hline Tota & 2291. & & & & & & & \\
\hline 1 & 7 & 500.9 & 405.4 & 19.0 & 34.8 & 43.5 & 1445.5 & 448.8 \\
\hline $\begin{array}{l}\text { Mea } \\
\text { n }\end{array}$ & 71.6 & 15.7 & 12.7 & 0.6 & 1.1 & 1.4 & 45.2 & 14.0 \\
\hline
\end{tabular}

Source: Authors' Field work, 2019

Table 2 contains result on soil properties in the thirtytwo (32) selected settlements in Kereke watershed. The soil properties considered in this study were textural classes (percentage sand, clay and silt), organic carbon, organic matter content, bulk density, soil porosity, moisture content and soil structure. These soil variables were considered because of their impacts on soil erosion, especially the initiation of gullies. The mean particle size distribution in the soil was sand $(71.6 \%)$, clay $(15.7 \%)$ and silt $(12.7 \%)$. Organic carbon $(0.6 \%)$, organic matter $(1.1 \%)$, bulk density $\left(1.4 \mathrm{gcm}^{-3}\right)$, soil porosity $(45.2 \%)$ and moisture content $(14.0 \%)$. The particle size distribution shows a very high percentage of sand particles compared to clay and silt in the soil samples. The soil samples have a mean soil textural class of sandy-clay. This type of soil is moderately loose in nature, with moderate to high infiltration rate as revealed by the high percentage of sand particles and porosity in the soils. These findings confirmed those of Aneke (1991) who reported that soils in the Benue valley are predominantly sandy and made up of lovisols and cambisols that are moderately erodible. However, in settlements where clay particles are moderate in content such as Lowcost housing estate, Agan, Asamakaha, Ajo, Kadaroko, Gogo and Agyaragu; infiltration may be limited due to low permeability of the clay particles which does not readily allow easy water infiltration into the soils. The initiation of gully erosion and flooding in some parts of the watershed could be attributed to nature of the soils with high percent sand that are unconsolidated, the impact of raindrop on the earth surface which helps to dislodge the loose particles and entrain them. The moderate rainfall intensity and energy experienced in the study area contributes to eroding the soils especially on steep slopes. The organic matter and organic carbon contents of the soils are very important chemical characteristics of soils that influences the production of humus that help to bind the soil particles together, to enhance its cohesiveness and ability to withstand or resist the tractive force of runoff. The organic matter 
content in the soils showed moderate values, with a mean value of $1.1 \%$. With this amount of organic matter content in the soils of the Kereke watershed, the soils will be moderately erodible, but more during periods of high intensity of rainfall in the area. This is because organic matter helps to build soil's resistance against shearing effect of surface wash; however, in periods of high intensity of rainfall, the soils would become loose, dislodged and carried downslope by overland flow. The soil bulk density is the relative weight of the soils in its natural state before oven dried. The mean bulk density of soils in the study area is $1.5 \mathrm{gcm}^{-3}$. The determined bulk density of the soils is moderate and has implication on the erodibility of the soils. With this moderate soil density in the study area, under dense vegetal cover, high organic matter content and reduced raindrop impact the soils may not be easily removed. These findings agreed with those of Houston, Tranter and Miller (2013) who reported that soil bulk density and soil organic matter content are important soil properties that influences soil erodibilty to the tractive force of runoff especially on steep slope. In the study area, the moderate bulk density and soil organic matter content could be attributed to the moderate depth of litter cover and vegetation cover in the area. The mean value of soil porosity in the study area is $45.2 \%$ and the moisture content is $14.0 \%$. The mean value of soil porosity is considered moderate. Porosity is influenced by particle size distribution in the soils. The relative high amount of sand and clay particles in the soils compared to silt particles influenced the porosity of the soils. The soil porosity and moisture content of the soils are very important indices for assessing gully erosion initiation at a drainage basin scale. This is because soil porosity and moisture content are surrogate measure of infiltration capacity of the soils. Notwithstanding, clay particles have high amount of tiny pore spaces that limits infiltration of water. With the moderate amount of clay particles in the soils, it is probable that infiltration will be moderate, due to high percent of sand particles that would influence infiltration. However, because of the high content of sand particles in the soil samples, the soils are moderately drained and entrained by hydrological processes. Figure 3 shows the soil particle size distribution pattern in the study area. It is obvious from Figure 3 that sand particle size distribution is above $60 \%$ in all the thirty-two samples collected from the field, and this was considered high. Clay particle size distribution was moderate in the soil samples, with value exceeding $20 \%$ in Ajo settlement. While silt particles were found to be low and below $20 \%$ in all the thirty-two soil samples. The high percentage of sand particles compared to clay and silt particles is indication that the soils are coarse in nature and could be moderately entrained during high intensity of rainfall. Table 3 contains soil structural classes in the study area.

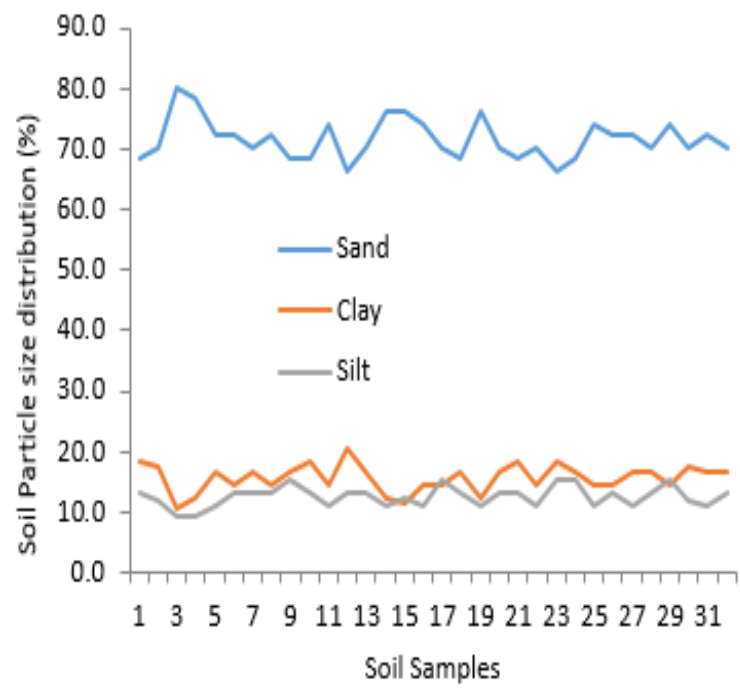

Fig. 3: Pattern of soil particle size distribution in the study area Source: Authors' field work, 2019

Table 3: Soil Structure as observed on the field

\begin{tabular}{|c|c|c|}
\hline Soil sample & Settlement & Soil structure \\
\hline 1 & $\begin{array}{l}\text { Fed.Lowcost North } \\
\text { bank Makurdi }\end{array}$ & Crumb \\
\hline 2 & Agan & Fine granular \\
\hline 3 & Daudu & Coarse granular \\
\hline 4 & Ikpam & Crumb \\
\hline 5 & Gide & Coarse granular \\
\hline 6 & Iyorkya & Fine granular \\
\hline 7 & Akiki & blocky \\
\hline 8 & Kwabo & Coarse granular \\
\hline 9 & Gever & Crumb \\
\hline 10 & Asamakaha & Coarse granular \\
\hline 11 & Ukpiam & Blocky \\
\hline 12 & Ajo & Blocky \\
\hline 13 & Kyaan & Coarse granular \\
\hline 14 & Usan & Coarse granular \\
\hline 15 & Amala & Crumb \\
\hline 16 & Agena & Fine granular \\
\hline 17 & Hinyam & Coarse granular \\
\hline 18 & Yerewata & Crumb \\
\hline 19 & Ande & Block \\
\hline 20 & Kyabo & Coarse granular \\
\hline 21 & Kadaroko & Coarse granular \\
\hline 22 & Akumba & Crumb \\
\hline 23 & Gogo & Fine granular \\
\hline 24 & Achuwa & Blocky \\
\hline 25 & Gaval & Crumb \\
\hline 26 & Giza & Coarse granular \\
\hline 27 & Ume & Blocky \\
\hline 28 & Adobi & Crumb \\
\hline 29 & Aloshi & Coarse granular \\
\hline 30 & Agyaragu & Crumb \\
\hline 31 & Adugu & Fine granular \\
\hline 32 & Agaza & Coarse granular \\
\hline
\end{tabular}

Source: Authors' field work, 2019

The soil structure in the study area was mainly coarse granular, followed by crumb, blocky and fine granular. 
The dominant soil structures were found to be coarse granular and crumb, and it presupposes that the soil surface horizons are unconsolidated, and could negatively influence erodibility of the soils, especially on steep slopes. The properties of the soils in the Kereke watershed presupposed that gully initiation and flooding is likely due to the unconsolidated nature of the sandy soil at the surface horizons of the soils; which are easily detached and entrained by raindrop impact. The soil properties therefore positively predicts the rate at which sediment is entrained within the Kereke watershed. The findings of this study confirmed those of Omon and Oisasoje (2012) in Benin city where it was observed that soils rich in sand particles influenced soil erosion in the area due to their easily entrained nature Hence, Omon and Oisasoje (2012) concluded that to protect the top soils from storm water and runoff, regulation of land use types, the use of manual brakes should be encouraged especially where money for the control of soil erosion is lacking amongst others. In the Kereke watershed the high percent of send particles observed was attributed to the nature of the superficial geology in the area, which is made up of predominantly sand stones.

Soil Erodibility Factor and its Influence on Hydrologic Processes in the Study Area: The soil erodibility $\mathrm{k}$ - value remains significant in determining the susceptibility of soils to the shear stress of detachment and entrainment by runoff. The soil erodibility factor in the study area was determined using the Revised Universal Soil Loss equation (RUSLE) as shown below.

The soil erodibility k-value in the study area was found to be 0.018 or $1.8 \times 10^{-2}$. According to Okorafor et'al (2017) soil erodibility $\mathrm{k}$ value less than or equal to 0.02 is considered low, with low erodibility effects. Therefore, the soil erodibility k-value in the study area was considered to be low; implying that the susceptibility of the soils in the study area to gully erosion is minimal. The low erodibility $\mathrm{k}$-value in the Kereke watershed was attributed to the moderate percentage of clay particles, depth of litter cover and organic matter in the soils which enhances its cohesiveness, infiltration and resistance to runoff. The low erodibilty $\mathrm{k}$ - value observed in the study area implied that hydrological processes such as runoff, erosion by water and flooding will be minimised due to moderate resistance of the soil to removal and detachment. This explains the reason for the moderate intensity of soil erosion and flooding observed and reported in the Kereke watershed. This findings corroborated that of Okorafor et'al (2017) in Imo State, where it was discovered that soils with low to moderate erodibility $\mathrm{k}$-values of $0.023,0.045$ and
0.039 were moderately prone to soil erosion, compared to areas with high erodibility-k values. Figures 1 and 2 shows an incised gully channel and flood site in the study area.

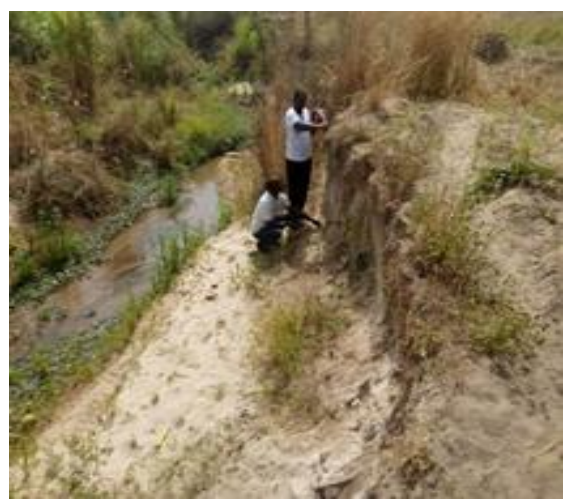

Plate 1: Incised gully channel at Daudu settlement in the study area

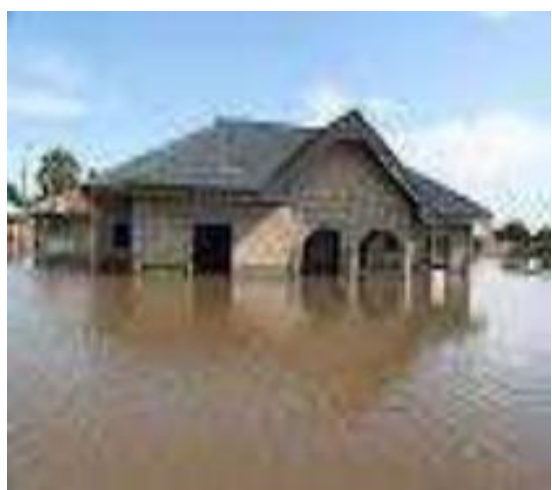

Plate 2: Submerged house due to flash flood in the study area Source: Authors' field work, 2019

Conclusion: The study area contained soils with high amount of sand and moderate amount of silt and clay particles. The erodibility k-value in the study area was considered to be low, and therefore the soils are moderately erodible. This was attributed to high amount of sand and moderate amount of clay particles in the soils that enhances infiltration, and resistance to detachment and removal by hydrological processes. This probably accounted for the moderate intensity of soil erosion channels observed in the study area, and recently deposited alluvium on flood plains of River Benue. Therefore, soil management practices should be encouraged by farmers, especially planting of cover crops, shifting cultivation and fallowing system, to allow nutrients gain and improved bulk density to limit its erodibility capacity.

\section{REFERENCES}

Aneke, DO (1991). Erodibility of Luvisol and Luvisil, Cambisol of Benue State. Journal of Agricultural Science and Technology, (1): 50-53 
Benkhelil, J (1989). The Origin and Evolution of the Cretaceous Benue Trough. Journal of African Earth Scientists, 8: 257-282

Brady, NC; Weil, RR (1999). Elements of the Nature and Properties of Soils. New York: Macmillan Publishers.

Brady, NC; Weil (2000). Elements of the Nature and Properties of Soils. New York: Macmillan Publishers.

Houston, A; Tranter, G; Miller, I (2013). Bulk Density. Retrieved from http://www.usyd.edu.au/agric/web04/Bulk\%20d ensity\%20the\%20final.htm on $12^{\text {th }}$ September, 2019.

Iorkua, SA (1999). A Gully in North Bank Area of Makurdi Benue State. Unpublished M.Sc. Dissertation, University of I badan, Ibadan, pp 3548.

Iorkua, SA; Ati, O; Songu, GA; Yiye, ST; Saidu, VA; Dambeki, IJ (2018). The Socio-Economic Effect of Flooding in the Benue Trough (A Case Study of Makurdi, Lokoja and Jalingo Towns). Inter. J. So. Sci. 1(13):46-56.

Ministry of Land and Survey, Makurdi (2016). Location of the Study Area.

Nyle, A; Brady, NC (2000). The Nature and Properties of Soils. New York: Prentice Hall Publishers.

Nigerian Meteorological Weather Office, Makurdi (2015). Rainfall Data in Makurdi. Retrieved on $2^{\text {nd }}$ February, 2015.

Office of the Surveyor General of Nigeria (2016). Topographic Maps of Makurdi. Retrieved on $3^{\text {rd }}$ June, 2016.

Okorafor, OO; Akinbile, CO; Adeyemo, AJ (2017). Determination of Soils Erodibility Factor (K) for Selected Sites in Imo State, Nigeria. Resources and Environment, 8 (1): 6-13
Omon, E J; Oisasoje, OM (2012). Aspects of Gully Erosion in Benin City, Edo State, Nigeria. Research on Humanities and Social Sciences, 7(20):22-35.

Ostovari, Y (2019). Soil Erodibility and its Prediction in Semi-arid regions. Retrieved on $14^{\text {th }}$ Febuary, 2021 from https://www.tandfonline.com/doi/abs/10.1080/03 $\underline{650340.2019 .1575509}$

Shahrivar, A; Christopher, TBS (2012). The Effects of Soil Physical Characteristics on Gully Erosion Development in Kohgiloyeh and Boyer Ahmad Province, Iran. Adv. Environ. Biol. 6(1): 367-405.

Songu, GA (2019). Thresholds of Environmental Factors of Gully Erosion in Kereke Drainage Basin of the Benue Trough. An Unpublished Ph.D thesis submitted to the Postgraduate School, Benue State University, Makurdi.

Songu, GA; Oyatayo, KT; Iorkua, SA (2015). Impact of Gully Erosion Stream Sedimentation in Demepke Drainage Basin. Am. J. Wat. Res. 4(3): 100-108.

Tyubee, TB (2005). Spatial Organization of Daily Rainfall in the Middle belt of Nigeria. The Benue Valley (41):69-71.

Udosen, CE (2013). Gully Erosion and Cities: An Unwanted Partnership. A paper presented at the faculty of Social sciences Seminar at CBN Hall, University of Uyo, pp 1-15

Wischmeier, WH; Smith, DD (1978). Predicting Rainfall Erosion Losses. A Guide to Conservation Planning. United States Department of Agriculture handbook.

Wischmeier, WH; Johnson, CB; Cross, BV (1971). A Soil Erodibility Monograph for Farmland and Construction Sites. J. Wat. Soil Conserve. 26:189193. 